\title{
Health impact assessment of air pollutants during the COVID-19 pandemic in a Brazilian metropolis
}

\author{
Marcos Lorran Paranhos Leão ${ }^{1}$ - Julia Oliveira Penteado ${ }^{2,3} \cdot$ Sabrina Morales Ulguim ${ }^{2} \cdot$ Rômulo Reginato Gabriel $^{2}$. \\ Marina dos Santos ${ }^{2,3} \cdot$ Aline Neutzling Brum ${ }^{3} \cdot$ Linjie Zhang $^{3}$ • Flavio Manoel Rodrigues da Silva Júnior ${ }^{2,3}$ (I)
}

Received: 8 February 2021 / Accepted: 22 March 2021 / Published online: 31 March 2021

(C) The Author(s), under exclusive licence to Springer-Verlag GmbH Germany, part of Springer Nature 2021

\begin{abstract}
Studies around the world have revealed reduced levels of atmospheric particulate matter in periods of greatest human mobility restriction to contain the spread of SARS-CoV-2 during the COVID-19 pandemic. The present study aimed to carry out a health impact assessment in Recife, Brazil, hypothesizing a scenario in which the levels of $\mathrm{PM}_{10}$ and $\mathrm{PM}_{2.5}$ remained, throughout the year, as in the most restrictive period of human mobility. Particular material data $\left(\mathrm{PM}_{10}\right.$ and $\left.\mathrm{PM}_{2.5}\right)$ were measured during the pandemic and population and health (mortality, hospital admissions for heart and respiratory problems) data from 2018 were used. We observed a reduction in the concentration of $\mathrm{PM}_{2.5}$ in up to $43.7 \%$ and $\mathrm{PM}_{10}$ up to $29.5 \%$ during the period of social isolation in the city of Recife. The reduction in $\mathrm{PM}_{2.5}$ would avoid 106 annual deaths from non-external causes and 58 annual deaths from cardiovascular diseases. In this scenario, \$294.88 million would be saved (\$114.88 million from heart problems and $\$ 180$ million from non-external causes). When considering hospitalizations avoided by the decrease in $\mathrm{PM}_{10}$, we observed 57 fewer hospitalizations for respiratory diseases, 42 for heart diseases and a reduction of 37 deaths due to non-external causes. The reduction in spending on respiratory and cardiovascular hospitalizations would exceed $\$ 330,000$. Therefore, the reduction of particulate matter could prevent hospital admissions, deaths and consequently there would be a reduction in disease burden in developing countries where economic resources are scarce. In this sense, governments should seek to reduce levels of pollution in order to improve the life quality and health of the population.
\end{abstract}

Keywords Recife $\cdot$ Particulate matter $\cdot \mathrm{SARS}-\mathrm{CoV}-2 \cdot$ Brazil $\cdot$ Health services

\section{Introduction}

At the end of 2020, 1 year after its first outbreak in Wuhan, China (Da Silva et al. 2020), COVID-19, a disease caused by

Responsible Editor: Lotfi Aleya

Flavio Manoel Rodrigues da Silva Júnior

f.m.r.silvajunio@gmail.com

1 Faculdade de Ciências Médicas (FCM) e Hospital Universitário Oswaldo Cruz (HUOC) da Universidade de Pernambuco (UPE) Campus Santo Amaro, Recife. Rua Arnóbio Marques, 310 - Santo Amaro, Recife, PE CEP: 50100-130, Brazil

2 Laboratório de Ensaios Farmacológicos e Toxicológicos, Instituto de Ciências Biológicas, Universidade Federal Do Rio Grande, Avenida Itália, km 8, Campus Carreiros, Rio Grande, RS CEP: 96203-900, Brazil

3 Programa de Pós-Graduação em Ciências Da Saúde, Faculdade de Medicina, Rua Visconde de Paranaguá 102 Centro, Rio Grande, RS, Brasil CEP: 96203-900 the new coronavirus (SARS-CoV-2) (Pedersen 2020), has caused almost 82.5 million cases and 1.7 million deaths worldwide. Brazil is one of the main countries mostly affected by the pandemic, presenting more than 7.6 million cases and about 193 thousand deaths, making the country the second in the number of deaths and the third in the number of confirmed cases in the world (WHO 2021).

SARS-CoV-2 infection can present in different clinical forms, with rapid spread due to high transmissibility. Before the advent of effective vaccines and specific antivirals, nonpharmacological interventions are the most efficient options in control of COVID-19 (Anderson et al. 2020; Cowling and Aiello 2020; Lai et al. 2020). Among the possible measures to contain the spread of infection, several countries have opted for social distancing and social isolation, which refers to the physical distance between infected and healthy individuals (Da Silva et al. 2020).

These measures to control social mobility have resulted in reduced traffic volume, decreased industrial production and 
other productive activities, closed airports, and closed borders. Thus, there was a decrease in pollutants released by anthropogenic activities. Many studies have indicated that the consequences of population isolation have contributed to a decrease in particulate emissions and a consequent improvement in air quality levels (Sperandio and Gomes 2020)

Particulate matter (PM) is a class of air pollutants that enter the human body through the respiratory tract and includes coarse particles (aerodynamic particle size up to $10 \mu \mathrm{m}$, $\mathrm{PM}_{10}$ ) and fine particles (measuring less than $2.5 \mu \mathrm{m}$, $\mathrm{PM}_{2.5}$ ), which are contributors to important adverse health effects observed in urban environments. $\mathrm{PM}_{10}$ is produced by mechanical processes, such as construction activities and road dust suspension, while $\mathrm{PM}_{2.5}$ originates mainly from combustion sources (USEPA 1996). The World Health Organization establishes safety limits for these pollutants in the atmosphere: average annual mean of $10 \mu \mathrm{g} / \mathrm{m}^{3}$ and $24-\mathrm{h}$ mean of $25 \mu \mathrm{g} / \mathrm{m}^{3}$ for $\mathrm{PM}_{2.5}$, and average annual mean of 20 $\mu \mathrm{g} / \mathrm{m}^{3}$ and 24-h mean of $50 \mu \mathrm{g} / \mathrm{m}^{3}$ for $\mathrm{PM}_{10}$ (WHO 2006).

Exposure above the permitted levels of $\mathrm{PM}_{2.5}$ and $\mathrm{PM}_{10}$ is related to a $3.4 \%$ increase in daily mortality rate from ischemic heart disease and respiratory diseases (Devos et al. 2015; Gouveia et al. 2003, 2006; Martins et al. 2004). In China, it was possible to observe a direct positive relationship between the concentration of $\mathrm{PM}_{2.5}$ and the emergency hospital admissions for total circulatory diseases, heart diseases, and coronary insufficiencies (Wang et al. 2018), as well as admissions for cerebral ischemic and hemorrhagic stroke (Liu et al. 2017; Zhang et al. 2018). Still, some studies relate $\mathrm{PM}_{10}$ to the increase in hospitalizations for asthma, respiratory and cardiovascular diseases, and cancer (Gouveia et al. 2017; Maciel et al. 2019; O’Neill et al. 2008).

In developing countries, such as Brazil, the health consequences of air pollutants can be even more serious due to poor socioeconomic conditions, lack of basic sanitation, unjustified income distribution, and poor quality of drinking water (Andersen 2017). Recife, the capital of Pernambuco, is the major important medical and technological center in Northeast Brazil and is the 4th most important metropolitan region in the country with more than 4 million inhabitants. A study from this city showed that the concentrations of $\mathrm{PM}_{2.5}$ and black carbon remain relatively constant over a whole year. Air pollution is related to vehicle and industrial emissions as well as emissions from maritime ships (De Miranda et al. 2012).

In this context, the Recife city was one of the worst areas at the beginning of the SARS-CoV-2 pandemic in Brazil. Until December 31, 2020, the state in which the city is located had more than 222 thousand confirmed cases and more than 9600 deaths (SEPLAG 2020). In addition, a Living Plan with COVID-19 was instituted at state, which provides for a gradual and planned resumption of economic activities and relaxation of the quarantine through 11 stages. There was a reduction in the emission of particulate material up to stage 10 (Pernambuco 2020). On October 12, 2020, Recife entered stage 10 in the Municipal Plan, which allowed the operation of numerous prohibited activities until that moment, among them, corporate events, street commerce, social events, amusement parks, cinemas, and theaters. Since that time, the levels of pollutants, especially $\mathrm{PM}_{2.5}$, have risen and returned to historic levels in the city. Thus, the present study aimed to carry out a health impact assessment at Recife, hypothesizing a scenario in which the levels of $\mathrm{PM}_{10}$ and $\mathrm{P}_{2.5}$ remained, throughout the year, as in the most restrictive period of human mobility.

\section{Material and methods}

\section{City and evaluated scenarios}

The study was carried out in the city of Recife (Fig. 1) located in the state of Pernambuco, in the Northeast region of Brazil. This city has approximately $1,653,461$ inhabitants and a territorial area of $218,843 \mathrm{~km}^{2}$ and is the main city in the Metropolitan Region of Recife, which has 15 municipalities and more than 4 million inhabitants (IBGE 2020). The data for $\mathrm{PM}_{2.5}$ and $\mathrm{PM}_{10}$ were obtained from April 25, 2020, to November 16, 2020, a period that included the city isolation decree (Period 1, more restrictive measures of urban mobility, April 26 to October 11, 2020; Period 2, less restrictive measures of urban mobility, between October 12 and November 16, 2020).

\section{Environmental data}

The measures of $\mathrm{PM}_{2.5}$ and $\mathrm{PM}_{10}$ were obtained from satellite data from the European Center for Medium-Range Weather Forecasts (ECMWF) "Copernicus Atmospheric Monitoring Service," extracted daily at $12 \pm 1 \mathrm{pm}$, with the aid of The Weather Channel (IBM, USA) APP.

\section{Population and health data}

Demographic and health data of Recife were collected through the database of the Unified Health System (DATASUS) in 2018 (DATASUS 2020). Information on morbidity and mortality rates from cardiovascular and respiratory diseases, mortality from non-external causes, and total mortality in the population were selected. Hospitalization data referring to both public and private hospitals were collected.

\section{Health impact assessment (HIA)}

The health impact assessment followed the methodology used in Pascal et al. (2013). We assess health benefits if 
Fig. 1 Map highlighting the city of study (Recife, Pernambuco State, Brazil)

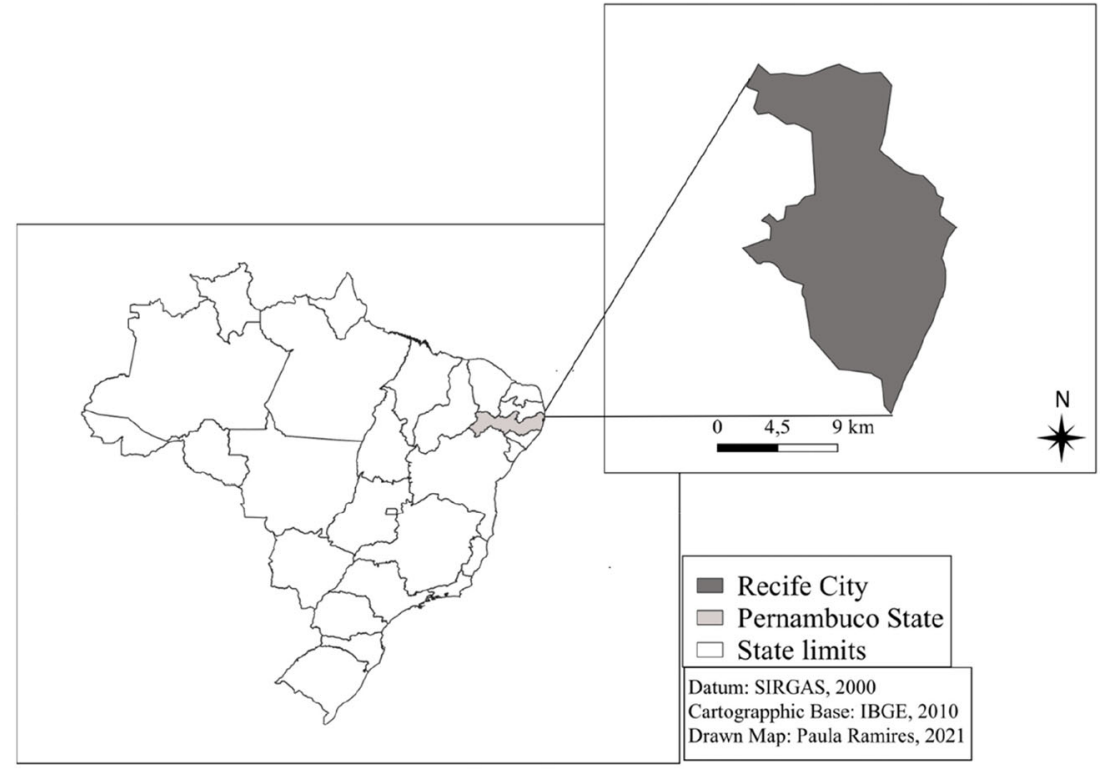

pollutant concentrations remain equal to average values obtained during the strictest period of social distancing and social isolation and control of human activities during the COVID-19 pandemic. For the short-term exposure to $\mathrm{PM}_{10}$, the health impact assessment was performed as:

$\Delta y=y_{0}\left(1-e^{-\beta \Delta x}\right)$

where:

$\Delta y$ is the decrease in the health outcome associated with the decrease in pollutant concentrations, in the annual number of deaths or hospitalizations.

$y_{0}$ is the baseline health outcome, in the annual number of deaths or hospitalizations.

$\beta$ is the coefficient of the concentration-response function.

$\Delta x$ is the decrease in the pollutant concentration in a given scenario, in $\mu \mathrm{g} / \mathrm{m}^{3}$

Regarding $\mathrm{PM}_{2.5}$ long-term health effect exposure, we applied a standard abridged life table methodology as described by Pascal et al. (2013) computed for:

$n D_{m}^{\text {impacted }}=n D_{x} \cdot e^{\beta \Delta x}$

where:

$n D_{\mathrm{m}}$ is the total number of deaths in the age group starting at age $n$ and covering $\mathrm{m}$ years.

$n D_{\mathrm{x}}$ is the number of deaths in a given 5-year interval (starting at age 30 to 85 or more)
We applied that function to 5-year age groups starting at age 30 , using the same $\beta$ for all age groups, to compute the average potential gain in life expectancy. Results were expressed as the number of postponed deaths and as gains in life expectancy at 30 . The annual survival burden, expressed as the total life years which could have been gained, was computed as the product of the average life expectancy at age 30 by the estimated number of population at age 30 .

All HIA calculations were performed using the Microsoft Excel® spreadsheet developed by the Aphekom project, available at http://aphekom.org/web/aphekom.org/. All detailed equations are provided in these tools.

\section{Deaths related to air pollution}

The estimate of deaths related to air pollution was carried out according to Ostro (2004). $\mathrm{PM}_{10}$ data were used to estimate deaths from non-external causes (mean after flexibility $=22$ $\mu \mathrm{g} / \mathrm{m}^{3}$ and background value $=10 \mu \mathrm{g} / \mathrm{m}^{3}$ ) and total mortality and cardiovascular mortality (data from $\mathrm{PM}_{2.5}$ (mean after flexibility) $=13 \mu \mathrm{g} / \mathrm{m}^{3}$ and background value $\left.=7.5 \mu \mathrm{g} / \mathrm{m}^{3}\right)$.

\section{Economic valuation on morbidity}

In relation to the economic costs of morbidity, expenses with hospitalizations due to respiratory and circulatory problems were calculated based on average cost per day and average hospital stay (Abe and El Khouri Miraglia 2016). Data on hospitalization costs and the average number of hospitalization days in the municipality of Recife were obtained through the DATASUS database, referring to the year 2018. 
Thus, the morbidity evaluation was estimated as follows (Eq. (3)):

$$
C h=V i \times N d \times N c
$$

where:

$$
\begin{aligned}
& \mathrm{Ch}=\text { cost of hospitalization } \\
& \mathrm{Vi}=\text { unit value of a daily admission } \\
& \mathrm{Nd}=\text { average number of admission days due to a certain } \\
& \text { disease } \\
& \mathrm{Nc}=\text { number of cases due to a certain disease }
\end{aligned}
$$

\section{Economic valuation on mortality $>30$ years}

Economic evaluation of mortality for $>30$ years was estimated according to Cora et al. (2020) using the formula below:

$C m=V d \times V S L$

where:

$\mathrm{Cm}=$ health cost by mortality for people over 30 years old $\mathrm{Vd}=$ deaths associated with air pollution

VSL = value of a statistical life, assigned as Bickel and Friedrick (2005) a value of $€ 1,000,000$ and converted to US dollar.

\section{Results}

The daily average concentration of $\mathrm{PM}_{2.5}$ and $\mathrm{PM}_{10}$ in the period of mobility restriction and the average of pollutants after reopening of activities in the city of Recife are shown in Table 1. The mean concentration of both pollutants was lower in the period of mobility restriction than that after reopening of activities. The reduction of pollutant $\mathrm{PM}_{2.5}$ was up to $43.7 \%$ and $\mathrm{PM}_{10}$ up to $29.5 \%$. The daily concentration of $\mathrm{PM}_{2.5}$ and $\mathrm{PM}_{10}\left(\mu \mathrm{g} / \mathrm{m}^{3}\right)$ throughout the mobility restriction period and after the resumption of commercial activities

Table 1 Mean concentration ( \pm standard deviation) of $\mathrm{PM}_{10}$ and $\mathrm{PM}_{2.5}$ during and after the period of high mobility restriction

\begin{tabular}{lll}
\hline Period & $\mathrm{PM}_{10}$ & $\mathrm{PM}_{2.5}$ \\
\hline During the period of high mobility restriction & $15.5 \pm 4.6$ & $7.33 \pm 1.7$ \\
After the reopening period of activities & $22 \pm 2.6$ & $13 \pm 1.5$ \\
\hline
\end{tabular}

in the city of Recife on October 12,2020 , is shown by a dispersion graph (Fig. 2).

Table 2 shows the annual average rate per 100,000 inhabitants of respiratory and cardiac admissions, and the total and non-external causes mortality for the year 2018 in Recife, in addition to the number of deaths related to air pollution and the relative percentage to all deaths. Among those over 30 years of age, the percentage of deaths related to air pollution was $4.3 \%$ when considering the total mortality, while $7.4 \%$ of deaths associated with cardiovascular diseases were attributed to air pollution. Approximately $1 \%$ of non-external mortality in all ages was attributed to air pollution

Table 3 shows the potential benefits of reduction in $\mathrm{PM}_{10}$ and $\mathrm{PM}_{2.5}$ on hospital admissions and mortality in the city of Recife, simulating a scenario where the levels of these pollutants would remain at the same level as during the period of greatest restriction of human activities in the COVID-19 pandemic. With the reduction of $\mathrm{PM}_{2.5}$ to $7.3 \mu \mathrm{g} / \mathrm{m}^{3}$, there would be a total of 106 annual non-external deaths avoided and 58 annual cardiovascular deaths avoided. When considering hospitalizations avoided by decreasing $\mathrm{PM}_{10}$ to $15 \mu \mathrm{g} / \mathrm{m}_{3}$, we estimated 57 fewer hospitalizations for respiratory diseases and 42 for heart diseases and a reduction of 37 deaths from nonexternal causes. The gain in life expectancy is 0.7 years.

Regarding economic benefits, the reduction in expenses with combined respiratory and cardiovascular hospitalizations would exceed 330 thousand dollars, while the monetary benefits related to total mortality, mortality from heart problems, and mortality from non-external causes were 114,88 , and 180 million dollars, respectively.

\section{Discussion}

Recife, the capital of the state of Pernambuco, was one of the Brazilian cities with the fastest spread of COVID-19 and one of the highest mortality rates related to COVID-19. Due to the accelerated curve, the local government acted quickly implementing measures that included suspension of educational activities and non-essential services and the encouragement of social distancing and home-office activities (Endo et al. 2020). In this sense, the rates of in loco social isolation exceeded $50 \%$ in the first 2 weeks of the implementation of the measures and remained for months (Endo et al. 2020). Interventions related to the prevention of COVID-19 led to the substantial decrease in the levels of $\mathrm{PM}_{2.5}$ and $\mathrm{PM}_{10}$ in the city of Recife.

The improvement in air quality has also been observed in other places in Brazil and in the world since the COVID-19 pandemic. In São Paulo, the largest air pollution center in Brazil, it was observed an estimated reduction of up to $29.8 \%$ in $\mathrm{PM}_{2.5}$ levels (Nakada and Urban 2020). New York showed a reduction of $24 \%$, Paris $28 \%$, and Los Angeles $37 \%$ 

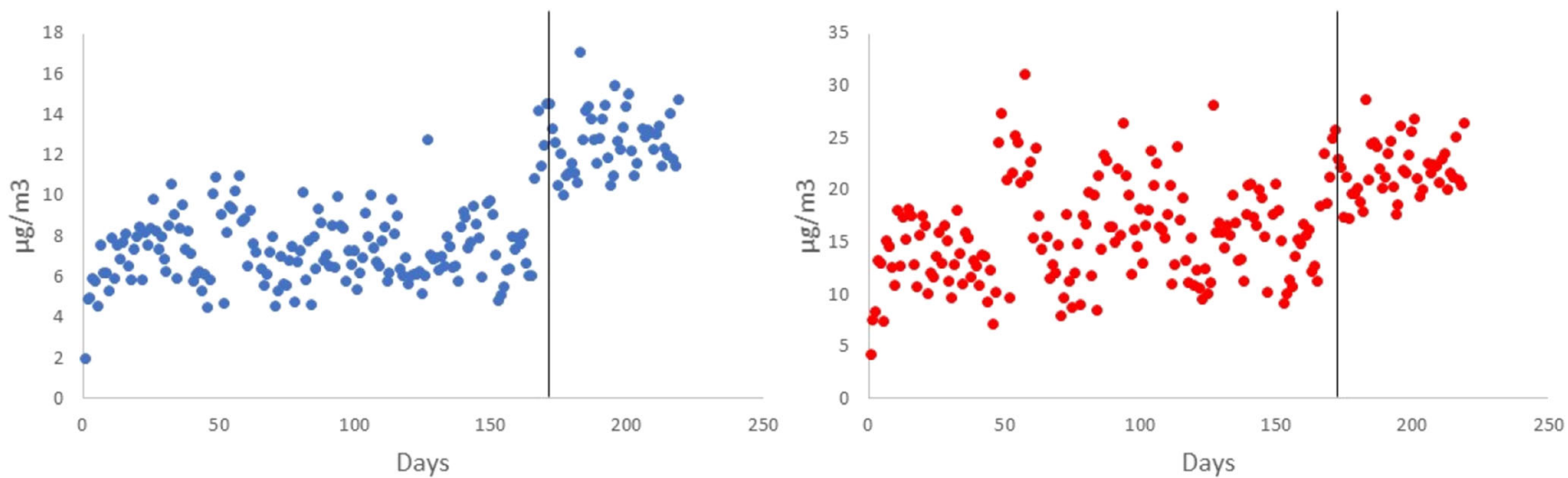

Fig. 2 Concentration of $\mathrm{PM}_{2.5}$ (left, blue circles) and $\mathrm{PM}_{10}$ (right, red circles) during and after the period of restriction mobility restriction in Recife, Brazil. The vertical line in each graph refers to October 12,2020 , date where services were fully opened in the municipality

(Connerton et al. 2020). This reduction in pollutant levels was directly related to the implementation of lockdown and other measures restricting the population, industries, and services (Kotnala et al. 2020; Markandeya et al. 2021).

In the Recife scenario, the control measures for dispersion of the SARS-CoV-2 were eased over time, and on October 12 , 2020 , the city entered stage 10 (penultimate stage) of the COVID-19 Living Plan. This step allowed activities such as corporate events, street commerce, social events, amusement parks, cinemas, and theaters and from that moment on, the levels of particulate matter returned to higher levels.

There are different sources of particulate matter in Recife, mainly emissions from ocean-going vessels that play an important role in the local economy, handling an average of 2.2 million tons of food and fertilizers. Still, particulate matter generated by multinationals installed in the region and the intense flow of vehicles affects air quality (De Miranda et al. 2012).

$\mathrm{PM}_{10}$ showed a smaller reduction (29.5\%) when compared to $\mathrm{PM}_{2.5}$ during the period of mobility restriction. The $\mathrm{PM}_{10}$ emission is not only related to the vehicle flow, other factors are involved such as the transport of air masses and meteorological parameters. In addition, diesel vehicles, which are the main contributors to the emission of particulate matter, maintained their activities to supply pharmacies, supermarkets, and gas stations (Dantas et al. 2020).

Particulate matter is considered an indicator of air quality associated with adverse health effects. There was an annual average of 7949 cases of hospitalization for respiratory problems in the city of Recife in 2018. Of these, 2113 were individuals $>65$ years old and 1899 aged $15-64$ years. In the case of the elderly, chronic exposure is aggravated due to the mechanism of gravitational sedimentation, the particles are deposited more in the lower airways than in the upper airways (Yoshizaki et al. 2017). Thus, the total, soluble, and insoluble fractions of the PM can interact with lung cells and cause adverse respiratory effects (Wang et al. 2018). In addition, an average of 11,188 cases of hospitalizations due to heart disease and 985 deaths due to cardiovascular diseases were recorded in Recife in 2018.

The number of deaths attributable to exposure to $\mathrm{PM}_{2.5}$ increased from 3.5 to 4.2 million from 1990 to 2015 (Cohen et al. 2017), becoming the fifth largest global contributor to disease worsening (Brauer et al. 2013). The chemical composition of $\mathrm{PM}_{2.5}$ (sebaceous nucleus, covered with sulfate, nitrate and metals/crustal elements) when associated with some

Table 2 The annual mean of respiratory and cardiac hospitalizations and total, non-external causes and cardiac mortality for 2018 in Recife, Brazil

\begin{tabular}{lllllll}
\hline Health outcome & ICD10 & Age & Annual mean & $\begin{array}{l}\text { Deaths related to } \\
\text { air pollution }\end{array}$ & $\begin{array}{l}\text { Percentage of deaths } \\
\text { related to air pollution }\end{array}$ & $\begin{array}{l}\text { Annual mean number } \\
\text { per } \\
100,000\end{array}$ \\
\hline Total mortality & A00-Y98 & $>30$ & 3448 & 148 & 4.3 & 352 \\
Cardiovascular mortality & I00-I99 & $>30$ & 985 & 73 & 7.4 & 101 \\
Non-external mortality & A00-R99 & All & 9848 & 94 & - & 596 \\
Cardiac hospitalizations & I00-I52 & All & 11188 & - & - & 677 \\
Respiratory hospitalizations & J00-J99 & $15-64$ & 1899 & - & - & 115 \\
Respiratory hospitalizations & J00-J99 & $>65$ & 2113 & - & - & 481 \\
Respiratory hospitalizations & J00-J99 & All & 7949 & - & & \\
\hline
\end{tabular}


Table 3 Potential health benefits of reducing daily $\mathrm{PM}_{10}$ and $\mathrm{PM}_{2.5}$ levels on hospitalizations and non-external mortality and cardiovascular mortality, in Recife, Brazil

\begin{tabular}{|c|c|c|c|c|c|}
\hline & $\mathrm{s}$ & $\begin{array}{l}\text { Annual number of } \\
\text { deaths avoided per } 100,000\end{array}$ & Gain in life expectancy & Life years gain & $\begin{array}{l}\text { Monetary valuation } \\
\text { US\$ millions }\end{array}$ \\
\hline \multicolumn{6}{|c|}{ Decrease to $7.3 \mu \mathrm{g} / \mathrm{m}^{3}$ in $\mathrm{PM}_{2.5}$ levels } \\
\hline Total mortality & 106.1 & 10.8 & 0.7 & 1531.8 & 114.38 \\
\hline Total cardiovascular mortality & 58.1 & 5.9 & - & - & 88.83 \\
\hline \multicolumn{6}{|c|}{ Decrease to $15.5 \mu \mathrm{g} / \mathrm{m}^{3}$ in $\mathrm{PM}_{10}$ levels } \\
\hline Total non-external mortality & 37.4 & 2.26 & - & - & 180.09 \\
\hline Respiratory hospitalizations & 57.1 & 3.45 & - & - & 0.14 \\
\hline Cardiac hospitalizations & 42.5 & 2.57 & - & - & 0.19 \\
\hline
\end{tabular}

viruses and bacteria on the particulate surface can increase its toxicity, increasing the risk of cardiorespiratory diseases and worsening health status (Feng et al. 2016; Zou et al. 2016).

In this analysis, we used air quality data obtained during the control interventions adopted in response to COVID-19 in Recife and we created a scenario where the annual averages of $\mathrm{PM}_{10}$ and $\mathrm{PM}_{2.5}$ were equal to the averages obtained in the period of greatest restriction of activities and services and of human mobility. We estimated a total of 164 avoided deaths attributable to air pollution by $\mathrm{PM}_{2.5}$ and 37 by $\mathrm{PM}_{10}$. In the same period, in China, 3214 deaths were avoided related to the reduction of $\mathrm{PM}_{2.5}$ (Chen et al. 2020), data also observed in Seoul Korea (Han and Hong 2020), in the city of Paris, and Marseille (Magazzino et al. 2020). These scenarios for reducing hospital admissions and mortality are capable of predicting economic benefits, and in the case of this simulation in Recife, the costs saved would be more than 380 million dollars.

The COVID-19 pandemic has had devastating effects on society and the global economy. However, it was observed an improvement in air quality due to reduction of anthropogenic emissions of pollutants because of mobility restriction adopted in the city of Recife and elsewhere in the world. These findings suggest that the reduction of air pollutants and improvement of air quality could have significant health benefits and economic savings.

\section{Conclusion}

The scenario simulated in the present study showed a significant reduction in hospital admissions and preventable deaths during the period of social isolation in Recife due to reduce levels of $\mathrm{PM}_{10}$ and $\mathrm{PM}_{2.5}$. These health responses are accompanied by economic benefits for the government and the set of information should be used to plan strategies to promote environmental health. We encourage to implement global effective strategies to reduce emissions of air pollutants and improve air quality, reinforcing the importance of a healthy environment for maintaining health and quality of life.

Acknowledgements The authors thank the Coordenação de Aperfeiçoamento de Pessoal de Nível Superior, CAPES, for the Doctoral scholarships (JOP and MS).

Author contributions M. L. P. L. and J. O. P. were responsible for writing the article and analyzing and interpreting the data. S. M. U., R. R. G., and A. N. B. were responsible for extracting the data from the databases and preparing the spreadsheets. M. S. and L. Z. helped to formulate the key research question and to correct the text. F. M. R. S. J. was the advisor and responsible for the research.

Funding This study was financed in part by the Coordenação de Aperfeiçoamento de Pessoal de Nível Superior - Brasil (CAPES) Finance Code 001 and Conselho Nacional de Desenvolvimento Científico e Tecnológico - 310856/2020-5

Data availability The datasets used and/or analyzed during the current study are available from the corresponding author on reasonable request.

\section{Declarations}

Ethics approval and consent to participate Not applicable

Consent for publication Not applicable

Competing interests The authors declare no competing interests.

\section{References}

Abe KC, El Khouri Miraglia SG (2016) Health impact assessment of air pollution in São Paulo, Brazil. Int J Env Res Pub He 13(7):694. https://doi.org/10.3390/ijerph13070694

Andersen MS (2017) Co-benefits of climate mitigation: counting statistical lives or life-years? Ecol Indic 79:11-18. https://doi.org/10. 1016/j.ecolind.2017.03.051

Anderson RM, Heesterbeek H, Klinkenberg D, Hollingsworth TD (2020) How will country-based mitigation measures influence the course of the COVID-19 epidemic? Lancet 395(10228):931-934. https://doi. org/10.1016/S0140-6736(20)30567-5 
Bickel P, Friedrick R (2005) ExternE - Externalities of Energy Methodology 2005 Update. Luxemburgo. Available in: http:// www.externe.info/. Accessed 01 Dec 2020

Brauer M, Freedman G, Frostad J, van Donkelaar A, Martin RV, Dentener F, Dingenen R, Estep K, Amini H, Apte JS, Balakrishnan K, Barregard L, Broday D, Feigin V, Ghosh S, Hopke PK, Knibbs LD, Kokubo Y, Liu Y, Ma S, Morawska L, Sangrador JLT, Shaddick G, Anderson HR, Vos T, Forouzanfar MH, Burnett RT, Cohen A (2013) Ambient air pollution exposure estimation for the global burden of disease 2013. Environ Sci Technol 50(1):79-88. https://doi.org/10.1021/acs.est.5b03709

Chen K, Wang M, Huang C, Kinney PL, Anastas PT (2020) Air pollution reduction and mortality benefit during the COVID-19 outbreak in China. Lancet Planet Health 4(6):e210-e212. https://doi.org/10. 1016/S2542-5196(20)30107-8

Cohen AJ, Brauer M, Burnett R, Anderson HR, Frostad J, Estep K, Balakrishnan K, Brunekreef B, Dandona L, Dandona R, Feigin V, Freedman G, Hubbell B, Jobling A, Kan H, Knibbs L, Liu Y, Martin R, Morawska L, Pope CA III, Shin H, Straif K, Shaddick G, Thomas M, van Dingenen R, van Donkelaar A, Vos T, Murray CJL, Forouzanfar MH (2017) Estimates and 25-year trends of the global burden of disease attributable to ambient air pollution: an analysis of data from the Global Burden of Diseases Study 2015. Lancet 389(10082):1907-1918. https://doi.org/10.1016/S0140-6736(17) 30505-6

Connerton P, Vicente de Assunção J, Maura de Miranda R, Dorothée Slovic A, José Pérez-Martínez P, Ribeiro H (2020) Air quality during COVID-19 in four megacities: lessons and challenges for public health. Int J Env Res Pub He 17(14):1-24. https://doi.org/10.3390/ ijerph17145067

Cora B et al (2020) Impacto da poluição do ar na saúde pública em municípios com elevada industrialização no estado de São Paulo. Braz J Env Sci 55(4):498-509. https://doi.org/10.5327/Z2176947820200671

Cowling BJ, Aiello A (2020) Public health measures to slow community spread of COVID-19. J Infect Dis 221(11):1749-1751. https://doi. org/10.1093/infdis/jiaa123

Da Silva LLS et al (2020) Social distancing measures in the fight against COVID-19 in Brazil: description and epidemiological analysis by state. Cad Saude Pub 36(9):1-15. https://doi.org/10.1590/0102$311 \times 00185020$

Dantas G, Siciliano B, França BB, da Silva CM, Arbilla G (2020) The impact of COVID-19 partial lockdown on the air quality of the city of Rio de Janeiro, Brazil. Sci Total Environ 729:139085. https://doi. org/10.1016/j.scitotenv.2020.139085

DATASUS (2020) Departamento de Informática do SUS Informações de Saúde. Available online: http://datasus.saude.gov.br/informacoesde-saude/tabnet. Accessed 16 Dec 2020

De Miranda RM et al (2012) Urban air pollution: a representative survey of PM 2.5 mass concentrations in six Brazilian cities. Air Qual Atmos Hlth 5(1):63-77. https://doi.org/10.1007/s11869-010-0124-

Devos S, Cox B, Dhondt S, Nawrot T, Putman K (2015) Cost saving potential in cardiovascular hospital costs due to reduction in air pollution. Sci Total Environ 527-528(2):413-419. https://doi.org/ 10.1016/j.scitotenv.2015.04.104

Endo PT, Silva I, Lima L, Bezerra L, Gomes R, Ribeiro-Dantas M, Alves G, Monteiro KHC, Lynn T, Sampaio VS (2020) \#stayhome: monitoring and benchmarking social isolation trends in caruaru and the região metropolitana do recife during the COVID-19 pandemic. Rev Soc Bras Med Trop 53:1-4. https://doi.org/10.1590/0037-86820271-2020

Feng S, Gao D, Liao F, Zhou F, Wang X (2016) The health effects of ambient PM2.5 and potential mechanisms. Ecotoxicol Environ Saf 128:67-74. https://doi.org/10.1016/j.ecoenv.2016.01.030
Gouveia N, Mendonça GAS, Leon AP, Correia JEM, Junger WL, Freitas CU, Daumas RP, Martins LC, Giussepe L, Conceição GMS, Manerich A, Cunha-Cruz J (2003) Poluição do ar e efeitos na saúde nas populações de duas grandes metropóles brasileiras. Epidemiol Serv Saúde 12(1):29-40. https://doi.org/10.5123/ S1679-49742003000100004

Gouveia N, Freitas CU, Martins LC, Marcilio IO (2006) Respiratory and cardiovascular hospitalizations associated with air pollution in the city of São Paulo, Brazil. Cad Saude Publica 22(12):2669-2677. https://doi.org/10.1590/S0102-311X2006001200016

Gouveia N et al (2017) Air pollution and hospitalizations in the largest Brazilian metropolis. Rev Saude Publica 51:117. https://doi.org/10. 11606/s1518-8787.2017051000223

Han C, Hong YC (2020) Decrease in ambient fine particulate matter during COVID-19 crisis and corresponding health benefits in Seoul, Korea. Int J Env Res Pub He 17(15):5279. https://doi.org/ $10.3390 /$ ijerph 17155279

IBGE. Instituto Brasileiro de Geografia e Estatística (2020) Recife. Available in: https://cidades.ibge.gov.br/brasil/pe/recife/panorama. Accessed 01 Dec 2020

Kotnala G, Mandal TK, Sharma SK, Kotnala RK (2020) Emergence of blue sky over Delhi due to coronavirus disease (COVID-19) lockdown implications. Aerosol Sci Eng 25:1-11. https://doi.org/10. 1007/s41810-020-00062-6

Lai CC et al (2020) Asymptomatic carrier state, acute respiratory disease, and pneumonia due to severe acute respiratory syndrome coronavirus 2 (SARS-CoV-2): facts and myths. J Microbiol Immunol Infect 53(3):404-412. https://doi.org/10.1016/j.jmii.2020.02.012

Liu H, Tian Y, Xu Y, Zhang J (2017) Concentrations of ambient particulate matter and hospitalization for stroke in 26 Chinese cities: a crossover case study. AVC 48:2052-2059. https://doi.org/10.1161/ strokeaha.116.016482

Maciel CSM et al (2019) Poluição atmosférica: consequências para a saúde da população brasileira. J Med Health Prom 4(2):1153-1159

Magazzino C, Mele M, Schneider N (2020) The relationship between air pollution and COVID-19-related deaths: $\mathrm{Na}$ application to three French cities. Appl Energy 279(115835):2020. https://doi.org/10. 1016/j.apenergy.2020.115835

Markandeya et al (2021) Spatio-temporal assessment of ambient air quality, their health effects and improvement during COVID-19 lockdown in one of the most polluted cities of India. Environ Sci Pollut Res 28:10536-10551. https://doi.org/10.1007/s11356-020-11248-3

Martins MCH, Fatigati FL, Véspoli TC, Martins LC, Pereira LA, Martins MA, Saldiva PH, Braga AL (2004) Influence of socioeconomic conditions on air pollution adverse health effects in elderly people: an analysis of six regions in São Paulo, Brazil. J Epidemiol Commun H 58(1):41-46. https://doi.org/10.1136/jech.58.1.41

Nakada LYK, Urban RC (2020) COVID-19 pandemic: impacts on the air quality during the partial lockdown in São Paulo state, Brazil. Sci Total Environ 730:e139087. https://doi.org/10.1016/j.scitotenv. 2020.139087

O'Neill MS et al (2008) Air pollution and mortality in latin America: the role of education. Epidemiology 19(6):810-819. https://doi.org/10. 1097/EDE.0b013e3181816528

Ostro B (2004) Outdoor air pollution: assessing the environmental burden of disease at national and local levels. Genebra: World Health Organization (Environmental Burden of Disease Series, n. 5.) Available in: https://apps.who.int/iris/bitstream/handle/10665/ 42909/9241591463.pdf. Accessed 01 Dec 2020

Pascal M, Corso M, Chanel O, Declercq C, Badaloni C, Cesaroni G, Henschel S, Meister K, Haluza D, Martin-Olmedo P, Medina S (2013) Assessing the public health impacts of urban air pollution in 25 European cities: results of the Aphekom project. Sci Total Environ 449(2007105):390-400. https://doi.org/10.1016/j. scitotenv.2013.01.077 
Pedersen SF, HO YC (2020) SARS-CoV-2: a storm is raging. J Clin Invest 130(5):2202-2205. https://doi.org/10.1172/JCI137647

Pernambuco (2020) Plano de Convivência das Atividades Econômicas com a Covid-19. Available in: https://www.pecontracoronavirus.pe. gov.br/plano-de-convivencia-das-atividades-economicas-com-aCOVID-19-tem-cronograma-antecipado/. Accessed 01 Dec 2020

SEPLAG (2020) Secretaria de Planejamento e Gestão. COVID-19 em Dados. Available in: https://dados.seplag.pe.gov.br/apps/corona. html. Accessed 01 Dec 2020

Sperandio DG, Gomes $\mathrm{CH}$ (2020) Variações globais nos níveis de $\mathrm{NO}_{2}$ durante a pandemia do COVID-19 ( Coronavirus ): uma breve discussão sobre geologia e antropoceno. Holos 19(2):1-11. https:// doi.org/10.15628/holos.2020.10546

USEPA (1996) United States Environmental Protection Agency. Effects on materials. In: Air quality criteria for particulate matter. Available online: http.//www.epa.gov/nceawww1/pdfs/partmatt/vol2/ 0671ch09.pdf. Accessed 30 Dec 2020

WANG Y et al (2018) Associations between daily outpatient visits for respiratory diseases and ambient fine particulate matter and ozone levels in Shanghai, China. Environ Pollut 240:754-763. https://doi. org/10.1016/j.envpol.2018.05.029

WHO (2006) Air quality guidelines for particulate matter, ozone, nitrogen dioxide and sulfur dioxide. Global update 2005
WHO (2021) WHO (2021) World Health Organization. Coronavirus disease (COVID-19) weekly epidemiological update and weekly operational update. Available in: https://www.who.int/ emergencies/diseases/novel-coronavirus-2019/situation-reports. Accessed 15 Jan 2021

Yoshizaki K, Brito JM, Silva LF, Lino-dos-Santos-Franco A, Frias DP, e Silva RCR, Amato-Lourenço LF, Saldiva PHN, de Fátima Lopes Calvo Tibério I, Mauad T, Macchione M (2017) The effects of particulate matter on inflammation of respiratory system: differences between male and female. Sci Total Environ 586:284-295. https:// doi.org/10.1016/j.scitotenv.2017.01.221

Zhang RH, Liu G, Jiang Y, Li G, Pan Y, Wang Y, Wei Z, Wang J, Wang $Y$ (2018) Acute effects of particulate air pollution on ischemic stroke and hemorrhagic stroke mortality. Neurol frontal 9(827):2018. https://doi.org/10.3389/fneur.2018.00827

Zou Y, Jin C, Su Y, Li J, Zhu B (2016) Water soluble and insoluble components of urban PM2.5 and their cytotoxic effects on epithelial cells (A549) in vitro. Environ Pollut 212:627-635. https://doi.org/ 10.1016/j.envpol.2016.03.022

Publisher's note Springer Nature remains neutral with regard to jurisdictional claims in published maps and institutional affiliations. 